\title{
International Enforcement of Maintenance Obligations
}

\author{
Paolo Contini*
}

FAMIIY DESERTION and nonsupport has long been a serious social probF lem. Whenever a breadwinner leaves his home and fails to discharge his alimentary duty, which Blackstone regarded as "flowing from the law of nature,"1 a whole family unit is disrupted. The psychological and financial blow suffered by abandoned wives and children - as husbands are the most frequent offenders - is often irreparable. In numerous cases wives are unable to support themselves with their own means and must look to welfare agencies for assistance and guidance; children abandoned by their parents frequently are committed to orphanages. ${ }^{2}$ Thus, in addition to the personal tragedy for the people involved, a man's failure to support his family often results in a financial burden for the community. On the other hand, in countries where no adequate welfare services exist, abandoned dependents are likely to become hopelessly destitute.

Desertion, which is the most common cause of nonsupport of dependents, has been called "the poor man's divorce." It is a method frequently used to break the marriage relationship by those who cannot afford divorce proceedings. It is also a common occurrence in countries where divorce does not exist or is very difficult to obtain.

In some cases a runaway breadwinner remains within the same country; in other cases he repairs to another country to escape his maintenance obligations, or, having moved abroad for other reasons, subsequently ceases to support the dependents left behind.

There is little doubt that the problem has become more acute in recent years both within the various States and between different countries. In the United States, for example, the Social Security Administration estimated, in a study made in sixteen States, that among families assisted under the aid to dependent children program, the number of fathers deserting or separated without court decree increased by $25 \%$ between 1942 and 1948. It was also shown that the father's absence from home far outranked death and incapacity as the reason for the children's need for public assistance. ${ }^{3}$

* Dr. Juris., Italy; Member, District of Columbia Bar; Legal Counsellor, Legal Department of the United Nations; Legal Advisor to the Committee of Experts on the Recognition and Enforcement Abroad of Maintenance Obligations. All views expressed herem are the personal views of the author.

\footnotetext{
11 Br. Comar. *446.

2 It was estimated by the National Desertion Bureau that well over 25 per cent of children in orphanages nil the United States as public charges are not orphans, but deserted children. Zunser, Family Desertion: Some International Aspects of the Problem, 6 SOczad SERv. REv., No. 2 (1932).

3 Alling and Leisy, Am to Dependent Chmbrrn in a Postwar Year (Soctar Securuty Adar's, Pub. Assistance R. No. 17, 1950).
} 
The number of dependent children in receipt of public aid in the United States has grown from 941,000 in 1941 to $1,523,000$ in 1951, and payments have increased from 153 million dollars in 1941 to 553 million dollars in 1951. Although there are no statistics indicating how many dependents have been left without support by defaulters living in another country, their numbers have undoubtedly increased to a considerable extent since the Second World War. Before the conflict, the problem consisted inainly of men who migrated to another country-in inany cases with the intention of sending for their families as soon as they could afford it, and, having settled down in the new environment, estranged themselves froin their families and failed to support thein. The mass displacements of persons which have occurred during and after the war have brought about more family separations and inore cases of nonsupport. Furthermore, a new category of abandoned dependents has arisen, the many thousands of wives and legitimate or illegitinate children left without support by soldiers teinporarily stationed abroad and repatriated after having contracted maintenance obhigations in a foreign country.

The problem of nonsupport cannot be solved merely by giving dependents improved legal weapons with which to prosecute defaulters. Aid by public and private welfare agencies is often essential in locating defaulters and giving financial assistance and legal advice to dependents. It is of equal importance, however, that claimants for maintenance be enabled to enforce their rights by judicial action, without excessive difficulty, delay and expense.

The object of this article is to examine the legal problems connected with the civil enforcement of claims for maintenance by a dependent against a defaulter in another country, and the proposals which have been made to improve the present situation. ${ }^{5}$

\section{REMEDIES AVAILABLE TO CLAIMANTS FOR MAINTENANCE}

A dependent seeking to enforce his rights of maintenance against a defaulter in another country is faced with a number of obstacles which are often insuperable.

Theoretically, a claimant ${ }^{6}$ may choose between two courses of action: to bring suit in the foreign state where the respondent is present, or to bring suit in the state where the claimant is present.

However, the legal and practical difficulties ${ }^{7}$ of instituting proceedings

4F.S.A., Soctal Security Butc. (September 1952). The number of recipients under the Aid to Dependent Children program amounted to over two million in 1951 if payments made to the mothers of ehigible children are included. About $45 \%$ of those payments were made to families where the fathers were estranged, and inost of them had deserted the family or had not married the mother of the children. It should be noted that these data do not include the numerous cases of nonsupport which are not recorded because dependents do not apply for public assistance.

5 Criminal remedies, such as extradition of family deserters, are outside the scope of this article.

"The terms "claimant" and "respondent" are used throughout this article to conform with the expressions used in draft conventions prepared by the Committee of Experts. 
abroad are such as to discourage most dependents, usually women and children with inadequate financial resources, from even attempting to pursue the first method.

The other course is no less complicated. In the first place, it may be assumed that in most cases, especially those concerning migrants and soldiers stationed abroad, the claimant has not obtained a maintenance order before the departure of the breadwinner from the State where the claimant is present. Thus action would have to be instituted in that State against a respondent who is in a foreign country. In several countries, however, including the United States ${ }^{8}$ and England, ${ }^{9}$ courts could not entertain such an action for lack of jurisdiction in a personal action against a respondent who is in the territory of a foreign state. ${ }^{10}$

Thus the claims of a number of dependents would be eliminated at this stage. It would be possible for other claimants, however, to obtain a maintenance order against the respondent before his departure for a foreign country or, in States where a maintenance order may be given against a respondent abroad, ${ }^{11}$ even after such departure. ${ }^{12}$

We must now examine whether a dependent, having been awarded a maintenance order in the country where he is present, will be able to enforce his claim against a respondent abroad.

Since a maintenance order given by a court is to be regarded as a judgment, ${ }^{13}$ the procedure to be followed by a claimant is different, depending on whether the respondent is present in a State in which foreign judgments may be directly enforced as such or in a State under whose law that system is not known.

\section{Enforcement by Exequatur}

The method of direct enforcement of foreign judgments is practiced in a number of countries, including mainly the States governed by the civil law system. Under this procedure, a claimant may apply to a court for the

TE.g.: (1) It is difficult and expensive for a dependent to retain counsel in a foreign country; (2) in various jurisdictions aliens or non-residents are not allowed to institute legal proceedings unless they post security for costs; (3) it would often be necessary to take proof in the country where the claimant is present for transmission to the court seized with the action, and this is a lengthy and involved procedure.

8 Wallace v. United Electric Co., 211 Pa. 473, 60 Atl. 1046 (1905); Restatement, ConFIICT OF LAwS $\$ 77$ (1934).

9 Dicey, Conflict of Laws 180 (1949) (rule 28); Order XI, Rule 1 of the English Supreme Court.

10 As exceptions to this general rule, courts are deemed to have jurisdiction if the respondent has been personally served with process within the state where the action has been instituted, if he is domiciled within that state or if he has voluntarily submitted to the jurisdiction of its court. None of these exceptions, however, are likely to occur in actions for maintenance against respondents abroad.

11 E.g., Nethertands Code Civ. Proc. art. 828(a); France Code Crv. Proc. art. 59; Italy Code Civ. Proc. arts. 4, 18.

12 In addition, maintenance orders could be obtained in the United States, England and other countries where similar principles are applicable, in the cases falling under the exceptions mentioned in note 10, supra. (1948).

13 Gutteridge, The International Enforcentent of Maintenance Orders, 2 INr'L L. Q. 156 
grant of exequatur, or enforcement of a foreign judgment. The conditions upon which an exequatur may be granted are laid down in the domestic laws of the various States and the international treaties to which they are parties. $^{14}$ The conditions common to most countries are the following:

a) The foreign court must have had jurisdiction;

b) The original judgment must not be contrary to the public policy of the country where enforcement is sought;

c) It must be enforceable in the country where it was given;

d) It must be res judicata;

e) There must not be litigation pending before a court of the country where enforcement is sought on the same cause of action and between the same parties.

It is by no means easy for a maintenance order to get through all these exacting tests. ${ }^{15}$ For instance, the jurisdiction of the original court is determined by the enforcing court in accordance with the latter's rules of conflict of laws. ${ }^{16}$ Since there are considerable differences among the laws of the various countries regarding the principles of judicial jurisdiction, the exequatur is not infrequently denied to foreign judgments for failure to comply with this condition.

The requirement of public policy or "ordre public" is another rather unpredictable obstacle to the enforcement of maintenance orders. As Professor Gutteridge has put it: "These concepts have in one form or another been made to serve the purpose of a shield which may be interposed by a national court to prevent the enforcement of a foreign judgment which offends against the sense of justice of the court or embodies conclusions which differ from those which would have been reached if the national law had been applied."17

\section{Enforcement by Action Upon a Foreign Judgment}

In the countries belonging to the common law system and in some other States, ${ }^{18}$ the exequatur procedure is unknown. In order to give effect to a

14 See a compilation of the relevant provisions of domestic laws and international treaties regarding the enforcement of foreign judgments in Institut International pour l'Unification du Droit Privé, L'Exécution à l'Etranger des Obligations Alimentaries (Doc. 13(1), 1938), and Appendix (Doc. 13(2), 1949).

15 Additional requirements are imposed in certain countries. For instance, in JAPAN CODE Civ. Proc. art. 200; Gerdany Introductory LaW of the Civm Code arts. 13, 27; and DenMIARR LAW ON ADMmISTRATION OF JUSTICE \$222-a (1936) a foreign judgment may be enforced only on condition of reciprocity.

In France, a court would refuse the exequatur if the foreign court, in dealing with a question of conflict of laws arising in the course of the proceedings, has reached a decision not in conformity with the French rules of conflicts. See NIBOYET, 6 TraItí DE DroIT InTERNATIONAI Prrvé FrançaIs 112 (France 1950); Gutteridge, Reciprocity in Foreign Judgments, 13 BrTt. Y. B. INr'L L. 56 (1932).

10 NIBOYET, op. cit. supra note 15 , at 101.

17 Gutteridge, stspra note 13 , at 169.

18 The following states are listed by the International Institute for the Unification of Private Law, supra note 14 (Doc. 13(1)), as having legislation which does not permit the enforcement of a foreign judgment as such: Afghanistan, Denmark, Finland, Iran, Liberia, Liechtenstein, Netherlands, Norway, Sweden, certain Swiss cantons, USSR, Yemen. 
foreign judgment it is normally necessary to initiate new proceedings in the competent court, alleging the foreign judgment as a cause of action. ${ }^{10}$

Some British authors ${ }^{20}$ are of the opimion that, since a foreign judgment may be recogmized as conclusive in a new action brought upon it, in practice it is far easier to recover on a foreign judgment in England and in the United States than in countries using the exequatur system.

In so far as our subject is concerned, however, the obstacles to be overcome by a dependent seeking to recover on a foreign maintenance order in a country of the common law system, are perhaps greater than under the exequatur procedure. The difficulties connected with the institution of legal action abroad have already been mentioned. ${ }^{21}$ Furthermore, a foreign judgment will not be recognized if the foreign court lacked jurisdiction, as prescribed by the principles of Anglo-American law. Accordingly, recognition would be denied to a judgment given by a court of a foreign State against a person who was not a citizen or resident of that State, nor personally served therein, and did not voluntarily submit to the jurisdiction of the court. ${ }^{22}$ This would be likely to exclude most maintenance orders which might be obtamed in some countries by wives and children against foreign soldiers temporarily stationed in those countries. ${ }^{23}$

Another difficulty lies in the general rule that, in order to be recognized, a foreign judgment ${ }^{24}$ must be final, and therefore not subject to modification. Foreign maintenance orders and alimony decrees are not entitled to recognition if they may be modified by the court seized with the original action.$^{25}$ Although recognition has been generally granted to foreign maintenance orders with respect to lump sum payments ${ }^{26}$ and accrued instal-

10 In England and other parts of the Commonwealth there are important exceptions to this general principle. Several statutes [e.g., the Judgments Extension Act, 1868, the Foreign Judgments Reciprocal Enforcement Act, 1933, the Umform Reciprocal Enforcement of Judgments Act (Canadian)] provide for the direct enforcement of foreign judgments by a system of registration which is substantially similar to the exequatur procedure. This system was also embodied in the treaties concluded in 1934 by the United Kingdom with France and Belgium on the reciprocal enforcement of judgments. Furthermore, under the Maintenance Orders (Facilities for Enforcement) Act, 1920, special provisions have been made in the case of maintenance obligations whereby courts of summary jurisdiction are empowered to make provisional orders in absentia against persons residing in other parts of the Commonwealth, subject to confirmation and enforcement by the court where the respondent resides. These facilities are not apphieable, however, to maintenance orders made in countries outside of the Commonwealth. at 54.

20 BaIL, The Enforcement of Foreign JUdGments (1928); Gutteridge, supra note 15,

21 See text at note 7, supra.

22 Emanuel v. Symon, 1 K.B. 302 (1908). See also note 8, supra.

23 Supra note 11.

24 With respect to the Uinted States, this expression covers both judgments given in sister states under the Full Faith and Credit Clause, and judgments given in foreign countries.

25 Sistare v. Sistare, 218 U.S. 11 (1909). Sce also Maguire v. Maguire, 50 Ont. L.R. 100 (1921) and other British Commonwealth cases discussed in READ, Recognition AND ENForcemient of Foreign Judgments 70, n. 11 (1938) and WolfF, Private Internationar Law 265 (1950).

26 Dow v. Blake, 148 IIl. 76, 87, 35 N.E. 761, 764 (1893). 
ments, ${ }^{27}$ no such recognition is normally extended to future payments. ${ }^{28}$ The necessity of bringing a new suit to enforce payment every time a respondent falls behind in his instalments, is sufficient to discourage a dependent from trying to enforce a foreign maintenance order in a country belonging to the common law system.

The foregoing sketchy outline shows that in most countries a dependent seeking to obtain support from a defaulter abroad is confronted with legal difficulties, delay and expense which are often insuperable. The legal remedies available to a dependent under existing laws and treaties are largely nugatory. ${ }^{29}$

\section{ATTEMPTS TO IMPROVE EXISTING SITUATION}

For many years individuals and benevolent societies have been aware that the special situation of abandoned wives and children demanded a special solution to the problem of enforcement of foreign maintenance orders. ${ }^{\mathbf{3 0}}$

Several attempts have been made since the twenties to devise, on an international basis, legal means for the purpose of making it easier for dependents to obtain support from a defaulter abroad. In 1929, on the initiative of the League of Nations, the International Institute for the Unification of Private Law, which has its headquarters in Rome, began to work on this subject. After a considerable amount of preparatory work, the Institute convened a Committee of Experts ${ }^{31}$ which held two sessions, at Bruxelles in 1937 and at Santa Margherita Ligure in 1938, and cirew up a preliminary draft convention. ${ }^{32}$

The work was interrupted by the war. In 1948, on the initiative of the United Nations Social Commission, the Institute resumed the consideration of the draft for the purpose of bringing it up to date. The Institute convened

$2 \pi$ Lynde v. Lynde, 181 U.S. 183 (1901).

28 Barber v. Barber, 21 How. 582 (U.S. 1858), Lynde v. Lynde, supra note 27. However, California courts and those of a few other states have adopted a more liberal policy by permitting the establishment in the respondent state of a foreign alimony decree and its enforcement as a continuing judgment given in that state. Palen v. Palen, 12 Cal. App. 2d 357, 358, 55 P.2d 228, 229 (1936); Creager v. Superior Court, 126 Cal. App. 280, 14 P.2d 552 (1932). See also other California cases referred to in Jacobs, The Enforcement of Foreign Decrees for Alimony, 6 LAW \& ConTEMTP. ProB. 250, 264-266 (1939).

With respect to foreign judgments in general, a similar policy is reflected in CAX. CODE Crv. Proc. $\$ 1915$ which reads: "A final judgment of any other tribunal of a foreign country laving jurisdiction, according to the laws of such country, to pronounce the judgment, shall have the same effect as in the country where rendered, and also the same effect as final judgments rendered in this state."

20 The British Maintenance Orders (Facilities for Enforcement) Act, 1920, and the Oslo Convention of 1931, should be excepted from this general statement because, basically, they provide adequate remedies to dependents. The territorial application of these instruments is, however, limited to most of the British Commonwealth and the Scandinavian countries.

30 Zunser, supra note 2.

31 Mariano d'Amelio (Italy), Chairman; J. Basdevant (France), E. Borchard and F. Déak (United States), H. Ficker (Gernany), C. Gorgé (Switzerland), H. C. Gutteridge (Great Britain), C. Meyer (Denmark), T. Perassi (Italy), G. Sauser-Hall (Switzerland), Ch. de Visscher (Belgium), E. de Steller (Secretariat of the League of Nations), Members; A. Farner, C. Baldoni and S. Cerulli-Irelli of the Institute, Rapporteurs.

39 International Institute for the UnIfication of Private Law, Preitadratary Draft of a Convention on the Enforcensent Abroad of Madntenance Obligations Doc. 16 (1948). 
another Committee ${ }^{33}$ which met at the Hague in November 1949, and prepared a revised draft convention. ${ }^{34}$ This text, together with comments received from various Governments, was submitted by the Secretary-General of the United Nations to the Social Commission. ${ }^{35}$ After a discussion at the seventh session of the Social Commission in April, $1951,{ }^{36}$ and at the thirteenth session of the Economic and Social Council in August, 1951, ${ }^{37}$ the Council, by its resolution 390(XIII), requested the Secretary-General to "prepare a working draft of a model convention or of a model reciprocal law, or both," and to convene a committee of experts "with a view to formulating, on the basis of the working draft or drafts prepared by the SecretaryGeneral, the text of a model convention or model reciprocal law, or both, to be submitted to the Council not later than at its sixteenth session for its consideration and recommendations to Governments." The SecretaryGeneral prepared two working drafts. ${ }^{38}$ The Committee of Experts, ${ }^{30}$ which met in Geneva in August, 1952, prepared, on the basis of the SecretaryGeneral's working projects, a Draft Convention on the Recovery Abroad of Claims for Maintenance, and a Draft of a Model Convention on the Enforcement Abroad of Maintenance Orders, ${ }^{40}$ which were submitted to the Economic and Social Council.

\section{ANALYSIS OF THE DIFFERENT PROJECTS}

The basic task confronting the drafters of the various projects was to find a formula which might be used as a basis for one or more international instruments binding upon as many States as possible. Since the problem of abandonment and nonsupport is particularly acute as between emigration and immigration countries, it was essential that any proposed solution should be generally acceptable to both groups of countries, including therefore States belonging to the civil law system (such as Italy, Germany) and States belonging to the common law system (such as the United States, Canada, Australia).

In order to understand more thoroughly the principles inspiring the Committee's draft conventions now being considered by the Economic and Social Council, it will be useful to examine the main features of the drafts prepared by the Rome Institute and by the Secretary-General.

${ }^{83}$ M. Pilotti (Italy), Chairman; J. P. Niboyet representing J. Basdevant (France), E. M. Meijers (Netherlands), T. Perassi (Italy), B. A. Wortley representing H. C. Gutteridge (Great Britain), Members; M. Matteucci, Secretary General of the Institute, Secretary.

34 International Institute for the Unification of Private Law, Pretomitnary Dratt of a Convention on the Recogmtton and the Enforcensent Abroad of Matntenance ObitGATTONS Doc. 16(1) (1950).

35 UN document $E / C N .5 / 236$.

36 UN documents E/CN.5/SR.171 and $172 ; \mathrm{E} / 1982$.

37 UN documents E/AC.7/SR. 184 and $185 ; \mathrm{E} / \mathrm{SR} .494$.

38 UN documents E/AC.39/L.3 and E/AC.39/L.6.

39 E. M. Meijers (Netherlands), Chairnzan; H. E. Yntema (United States), Vice-Chairman; M. Matteucci (Italy), Rapporteur; Mme. M. Kraemer-Bach (France), K. Lipstein (United Kingdonı) replacing H. C. Gutteridge; E. A. Saleh (Lebanon), F. C. de San Tiago Dantas (Brazil), Members. W. Langrod and P. Contini of the United Nations Secretariat acted as Secretary and Legal Adviser to the Committee, respectively.

40 UN document E/AC.39/1. 


\section{The Rome Institute Draft of 1949}

The draft prepared by the Rome Institute ${ }^{41}$ was intended to provide a model for a multilateral convention based upon the exequatur system. No attempt was made to define the categories of dependents included within the scope of the draft. Thus the question of whether in any particular case a legal duty to support actually existed would be determined by the law of the court before which an action for maintenance was brought.

In accordance with Articles 2 and 5, a naintenance order ${ }^{42}$ given in the territory of a Contracting Party was to be recognized as res judicata and enforceable by exequatur in the territory of any of the other Contracting Parties provided that the following conditions were fulfilled:

1. That the decision emanate from an authority having jurisdiction in in accordance with Article 3 of this Convention;

2. That there be no appeal from the decision to a higher authority under the law of the country in which the decision was given; and that, in case of a decision by default, the time allowed to the defendant to contest the decision in the court where it was given, under the law of that country, be expired;

3. That the decision be enforceable according to such law;

4. That in case of a decision by default, the proceedings be duly instituted in accordance with the law of the country where the decision has been given. Recognition may nevertheless be refused if the authority applied to considers that the rights of the defence have not been respected, as would be the case for example where the defendant has not been personally served;

5. That the judgment be not inconsistent with a decision given on the sane matter and between the same parties in the country where it is invoked, or that the same dispute between the same parties has not been brought before a tribunal in that country prior to the determination of the decision invoked;

6. That the decision given against a citizen of the country where it is invoked, or against a person having his domicile or habitual residence there, shall not be contrary to the law of that country if such law be applicable according to its private international law;

7. That the decision shall not be against public policy in the country where it is invoked.

Article 3 provided that the following authorities would be competent to give maintenance orders:

1. The authorities of the country in whicli the defendant was liabitually resident when the proceedings were instituted;

2. The authorities of the country in which the plaintiff was habitually resident when the proceedings were instituted;

41 No reference will be made to the preliminary draft prepared by the Rome Institute in 1938 because it was superseded by the 1949 project.

42 In addition to maintenance orders given by judicial authorities, the draft applied to consent orders ("Transactions judiciaires"), instruments enforceable without the need for an action ("actes authentiques exécutoires") and decisions of administrative authorities. 
3. The authorities to the jurisdiction of which the defendant submitted either expressly or by entering upon a discussion of the merits of a matter without reservation as to jurisdiction.

The conditions which had to be fulfilled by a maintenance order to be entitled to recognition and enforcement are substantially similar to those which are generally found in existing laws and treaties. ${ }^{43}$ The main innovation of the Rome draft consisted in establishing the jurisdiction of the courts of the country where the plaintiff was habitually resident. This would extend the benefits of the convention to wives and children of foreign soldiers and other dependents who at present are often unable to obtain a maintenance order in the country where they reside or, if such order is granted, to have it enforced in the country where the respondent resides.

The prosecution of the claimant's action was further facilitated by several provisions: free legal aid (Article 12), exemption from posting security for costs or cautio judicatum solvi (Article 14), facilities for the transfer of sums awarded on account of maintenance obligations (Article 15). A novel feature of the draft was the clause whereby enforcement proceedings would be instituted ex officio and without cost by the appropriate authorities of a Contracting Party to which a foreign maintenance order on behalf of a person granted free legal aid had been transmitted through diplomatic channels (Article 13).

Most of the Governments which sent observations to the SecretaryGeneral commented favorably on the Rome draft. ${ }^{44}$ The Umited States, however, criticized it mainly on the ground that a judgnent rendered by a court in a foreign country against a person who was neither a national or citizen nor a domiciliary of such country, nor personally served with process in such country, and who did not voluntarily submit to the jurisdiction of such court, would not be recognized as valid, even if the foreign process were forwarded to him in the United States. ${ }^{48}$ Being unable to accept the provision of the Rome draft concerning the jurisdiction of the courts of the country of the plaintiff's habitual residence [Article 3(2)], the United States considered that the draft "would not offer a solution in the bulk of cases of unions between nuembers of fighting forces and women residing in foreign countries and also those of refugees and displaced persons." It was also observed that the exequatur procedure was not familiar to the courts of the United States and other common law countries, and was therefore not readily adaptable to the legal systems of those countries. For these reasons the United States was of the opinion that the draft was not in such form as to constitute an adequate working basis.

Having made these criticisms, the United States suggested that consideration might be given to a plan under which the machinery of justice in the

43 See text following note 14 , supra.

44 UN document E/CN.5/236, Annex III.

45 Id. at 33. Other basic objections to the draft vere raised by the United Kingdom and the Netherlands. (UN documents E/CN.5/236/Add. 1, and E/AC.39/L.2).

46 The same principle would also apply to other common law countries. See note 22 supra. 
country in which the dependents reside could be used in aid of proceedings instituted in the country which has jurisdiction over the respondent. The emphasis would thus be shifted from the enforcement of a foreign maintenance order to facilitating the obtaining of an order in the country where the respondent resides. This meant examining the possibility of adapting to the international field a system along the lines of the uniforn support legislation in force aniong many states of the United States. ${ }^{47}$

The Rome Institute sought to meet the United States objections by submitting an "Optional Clause" 48 whereby any Contracting Party, whilst remaining bound by the recognition clauses of the draft convention, would have the right to be exempted from granting enforcement by exequatur to foreign maintenance orders. A Party making this reservation would undertake to comply with other provisions by which (1) a petition could be presented to the judicial authorities of the country where the claimant resides; (2) those judicial authorities would transmit the petition to the judicial authorities of the country where the respondent resides, which would conduct proceedings ex officio; (3) there would be collaboration between the judicial authorities of the two countries in gathering evidence.

\section{The Secretary-General's Drafts}

In considering the best method of facilitating the international enforcement of maintenance obligations, the Secretary-General was aware of the importance of formulating an instrument which might be acceptable to the most important civil law and common law countries. A draft convention based exclusively upon the exequatur system was clearly not suitable for the common law system. On the other hand, the "optional clause" suggested by the Rome Institute would not solve the problem because in all probability States familiar with the exequatur procedure would choose that method, and States not familiar with the exequatur would adopt the systein of judicial collaboration. Thus the main substance of a convention containing the optional clause would not be in force as between civil law and common law countries.

The Secretary-General reached the conclusion that there should be two separate instrunients, one providing for the enforcement by exequatur of foreign maintenance orders, and the other based upon a systen of judicial collaboration between the two countries concerned in order to facilitate the obtaining of a maintenance order in the country where the respondent

4T The uniform support laws in force in forty-one jurisdictions have been classified as follows by Von Otterstedt, Reciprocal Support Legislation, CURRENT TRENDS IN STATE LEGISIATION 164-296 (Mich. U. Law School, 1952):

(1) Uniform Support of Dependents Act of 1949, adopted by nine states on the initiative of New York;

(2) New Jersey Act, adopted by two states;

(3) Virginia Act, adopted by one state;

(4) Uniform Reciprocal Enforcement of Support Act, prepared in 1950 by the National Conference of Commissioners on Uniform State Laws, adopted by 28 states and one territory.

48 UN document E/CN.5/236/Add. 2, Annex. 
resides. The first type of convention was primarily designed to be acceptable to civil law countries, including mainly Europe and Latin America; even though in several of those countries it is already possible to obtain the enforcement of foreign judgments by exequatur, the proposed international convention would codify and make uniform the existing law, and, in addition, would introduce important facilities and exemptions for the benefit of dependents. The second type of instrument was primarily designed to be acceptable to common law countries, especially the United States.

The two working drafts were not presented by the Secretary-General as alternatives, but as complementary to each other. Thus it was contemplated that an emigration country belonging to the civil law system, such as Italy, would enter into one or more conventions of the first type with other civil law States, including some neighboring and immigration countries such as France, Brazil, and Argentina. At the same time, Italy would enter into one or more conventions of the second type with common law countries, including some major immigration countries, especially the United States. Common law countries would be bound, as between themselves, by conventions of the second type, for example, a convention among the United States, Canada and the United Kingdom.

Working Draft of a Model Convention on the Enforcement of Maintenance Obligations. - This draft was generally patterned after the Rome Institute project. One important difference, however, was that the SecretaryGeneral limited the scope of the draft convention to the enforcement of foreign maintenance orders ${ }^{49}$ and did not include any provision for the recognition of such orders as res judicata.

The conditions of enforcement were substantially the same as those contained in Article 2 of the Rome draft, ${ }^{50}$ except for the following modifications:

(1) In the Rome draft [Article 2(4)] the enforcing court, in case of a decision by default, had discretionary power to determine whether the rights of the defence had not been respected "as would be the case for example where the defendant has not been personally served." It was considered by the Secretary-General that the broad mandate given to the enforcing court might enable the defendant to raise objections and defences which would unduly complicate and delay the enforcement proceedings. It was thought necessary, however, that the enforcing court should be satisfied that an absent defendant had actually received notice in sufficient time to act upon it. Accordingly, Article 3(c) of the Secretary-General's draft [corresponding to Article 2(4) of the Rome draft] read: ${ }^{\text {t1 }}$

49 Maintenance orders were confined to judicial acts of a court, and excluded therefore administrative decisions and "actes authentiques exécutoires," which were included in the Rome draft.

50 See text after note 42 , supra.

51 A similar clause is contained in the Conventions on Reciprocal Enforcement of Judgments concluded in 1934 by Great Britain with France and Belgium (art. $3 \mathrm{I}(\mathrm{b})$ ), and in the British Foreign Judgments (Reciprocal Enforcement) Act $\& 4(\mathrm{I})$ (a) (iii) (1933). 
Where the order was given by default the enforcing court is satisfied that the judgment debtor actually received notice in sufficient time to defend the proceedings. If the enforcing court considers that this requirement has not been observed enforcement may be refused even though such notice was served on the judgment debtor in accordance with the law of the country of the original court.

(2) The conditions set forth in paragraphs 2 and 6 of the Rome draft were omitted from the Secretary-General's draft.

Paragraph 2 prescribed that a foreign maintenance order must not be appealable. Since in some countries execution may be granted to a maintenance order even though it may still be subject to appeal, it was considered that, in order to avoid a delay which in some cases might cause hardship to an indigent dependent, this condition should be dispensed with.

The condition set forth in paragraph 6 of the Rome draft could give rise to considerable complications and uncertainty regarding the application of the convention because of the lack of uniformity in the private international law rules of different countries on the subject of the applicable law in matters of personal status. It was also considered that a foreign maintenance order should not be denied enforcement merely because it might not conform to some technicality of the law of the enforcing country.

(3) Whilst retaining the exception of public policy contained in the Rome draft (paragraph 7) the Secretary-General's draft limited it to cases in which the enforcement of the order would be manifestly contrary to public policy. Thus it was indicated that the exception was to be limited to cases in which the enforcement of a foreign maintenance order would be truly incompatible with the basic principles of the law of the enforcing country.

The rules establishing the competence of courts to pronounce maintenance orders (Article 4 of the Secretary-General's draft) were practically identical to those contained in Article 3 of the Rome draft, except that the concept of habitual residence was changed to residence.

Article 5 laid down the procedure to be followed in applying for the enforcement of a foreign maintenance order. ${ }^{52}$ The clause included in Article 13 of the Rome draft was basically reproduced in the Secretary-General's draft which provided that whenever an application is made through the diplomatic channel, "the proceedings for enforcement shall be conducted ex officio by the appropriate authorities of the country of the enforcing court."

Article 7 established that a foreign maintenance order which has been granted an exequatur or which has been registered "shall ... have the same force and effect as if it had been originally obtained in the enforcing court, and in particular it shall be enforceable in the same manner as a mainte-

52 The draft provided two alternative methods of enforcement, i.e., exequatur or registration of a foreign maintenance order. The latter was included on the theory that it inight be acceptable to countries of the British Commonwealth in which registration of foreign judgments is practised. See note 19 supra. 
nance order pronounced by that court." No analogous provision existed in the Rome draft, although the effect of the exequatur was undoubtedly intended to be the same.

Article 8 gave the enforcing court the power to vary the amount and rate of payments. It was considered that the enforcing court, being in the best position to ascertain the financial conditions of the respondent, should be allowed to increase or decrease the amount according to its judgment. A similar clause was to be found in Article 7 of the Rome draft.

The exemptions and facilities set forth in Articles 12 and 13 (free legal aid, exemption from costs and charges, exemption from posting security for costs, facilities in transfer of funds) correspond substantially to those provided in Articles 12,14 and 15 of the Rome draft.

The final clauses of the Secretary-General's draft (Articles 15-20) followed generally the pattern of recent conventions concluded under the auspices of the United Nations.

Working Draft of a Model Agreement on Maintenance Obligations.Taking the United States' suggestion as a starting point, ${ }^{63}$ the SecretaryGeneral sought to introduce on an international basis a new scheme of judicial collaboration which was generally inspired by the American uniform support laws.

Article 1 made the draft applicable to all persons having a right or a duty of support according to the law of the country of residence of the respondent (called "obligor" in the draft). Although the categories of persons covered by the convention were not specified, this provision sought to avoid any possible conflict between the laws of Contracting Parties with respect to the defimition of dependents and obligors.

Under Article 3 a dependent seeking to obtain a maintenance order against a person residing in the territory of another Contracting Party could file an application in the court im whose jurisdiction the dependent resided ("initiating court"). The initiating court, having inade a preliminary finding of the existence of a prima facie cause of action, was required to transmit the documents to the responding court through the authorities designated by the government of the responding state (Article 4). Thus dependents were given the facility of starting the machinery of justice in their own country, and the initiating court was relieved of the burden of ascertaining which was the coinpetent court in the foreign country where the obligor resided.

Upon receipt of the documents, proceedings against the obligor were to be commenced ex officio by the responding court (Article 5).

The Contracting Parties would undertake to represent the dependents, at their request, through the public authorities normally representing the government in legal proceedings (Article 6). A facility of this type, which was similar to the provision of Article 13 of the Rome draft ${ }^{\text {t4 }}$ and Article 5

53 See text at note 47 , supra.

os See text after note 43 , supra. 
of the first Secretary-General's draft, ${ }^{55}$ may be found, for example, in the Minnesota Reciprocal Enforcement of Support Act of 1951.

Article 7 set forth a simple procedure for the taking of proof by the initiating court in the state of residence of the dependent, at the request of the responding court.

Article 8 provided for the rendering of a maintenance order by the responding court in accordance with its law.

The exemptions and facilities, including transfer of funds, establislied in this draft correspond to those set forth in the first draft.

A dependent who had already obtained a maintenance order in his country of residence was enabled to avail himself of the benefits of the convention in seeking to obtain another order against the obligor in the latter's country of residence (Article 13). Such dependent would therefore have a choice of either applying for the enforcement abroad of the original maintenance order under the first draft, or applying for a new order under this draft.

\section{Drafts Prepared by the Committee of Experts}

Having considered the working drafts prepared by the SecretaryGeneral, the Committee ${ }^{56}$ formed the opinion that the main problem consisted in devising a method for obtaining a maintenance order in the respondent's country, rather than enforcing abroad a maintenance order rendered in the claimant's country. Simce in most instances the person liable has left the country where the dependents live before a maintenance order has been obtained in that country, the Committee thought that a convention for the purpose of facilitating the enforcement of foreign judgments would, in practice, cover only a few cases of nonsupport. Furtherinore, the exequatur procedure was not suitable to the legal systein of the United States and possibly of other common law countries; on the other hand, the inethod suggested in the Secretary-General's second draft was compatible with the law of those countries and at the same time was not inconsistent with any basic principle of the civil law.

For these reasons the Committee concentrated primarily on the preparation of a draft convention developing the solution envisaged in the Secretary-General's second draft. Being convinced that the adoption by as many States as possible of a multilateral convention on the terms of this draft would represent a real step forward, the Committee subimitted it to the Econounic and Social Council for consideration.

In addition, it was thought desirable that States should take steps to bring about a gradual unification in the present procedures for the enforcement abroad of maintenance orders. Accordingly the Committee submitted to the Council a second draft, based upon the Secretary-General's first work-

E5 See text at note 52 , supra.

E6 The official name was "Committee of Experts on the Recognition and Enforcement Abroad of Maintenance Obhgations." 
ing draft, which could be used by States.as a model for bilateral treaties or uniform legislation.

Draft Convention on the Recovery Abroad of Claims for Maintenance. - The Committee devoted a great deal of attention to the relationship between the authorities of the two States concerned in the prosecution of actions for manitenance. It considered that the procedure envisaged in the Secretary-General's second draft, establishing a system of close collaboration between courts, although suitable among different States of a federal umon, might be less appropriate on an international scale because of the existing differences in the judicial systems of the various countries. The Committee therefore endeavored to set up a mechanism which would be adequate for the purpose of assisting dependents. while at the same time changing as little as possible the procedures of different States.

The main outlines of the proposed system are the following:

Phase 1. A claimant for maintenance makes an application to an agency (called the transmitting agency) in the State in which the claimant resides or is present.

Phase 2. The transmitting agency makes a preliminary examination of the application, documentation and evidence for the purpose of determining summarily whether the clainı makes out a case for transmission. A hearing may be held during this phase.

Phase 3 . The transmitting agency forwards the papers regarding the claim to an agency (called the receiving agency) in the State in which the respondent is present.

Phase 4. The receiving agency is required to institute proceedings, with the assistance of counsel if necessary, against the respondent in the competent tribunal. The proceedings, including the rendering and enforcement of a maintenance order, are governed by the law of the tribunal.

The foregoing system is basically similar to the scheme set forth in the Secretary-General's second draft. However, the Committee, in order not to interfere with the competence and procedures of local courts, wanted to avoid the provisions of the Secretary-General's draft whereby the initiating and responding court were given certain special duties. Thus in the Committee's draft convention the functions assigned in the SecretaryGeneral's draft to the intiating court were attributed to the transmitting agency. Contracting States were left free to designate one or more transmitting agencies, to use for that purpose judicial or administrative authorities, to establish new organs or to use existing ones, and to attribute the different functions of the transmitting agency to separate authorities. Not even the designation of a transmitting agency was made mandatory. However, to ensure that the scheme would operate in all cases, it was prescribed that if a State has not designated a transmitting agency, any authority having the power to render maintenance orders may act as a transmitting agency [Article 2, (1), (2) and (3)].

On the other hand, each Contracting State was required to designate a public or private institution as the receiving agency in its territory, and to 
confer upon it the functions and powers laid down in the draft convention, because certainty on this point was considered essential to the operation of the systein [Article 2, (4)].

Although the draft convention left broad latitude to each Contracting State in the designation of the transmitting and receiving agencies, it would seem important that in each Contracting State the functions of transmitting agencies be given to local authorities or to local branches of a central authority, both for the convenience of the claimant and because a summary examination of the case and the hearing of witnesses should be conducted at the place of residence of the claimant. The receiving agency, on the other hand, was envisaged in the draft convention as a single authority in order that transmitting agencies should have no doubts as to which authority in a foreign country is competent to receive the papers. In each Contracting State a nationwide authority could act as the receiving agency, and might discharge through its local branches the duty of instituting proceedings in the competent court. ${ }^{57}$

The draft convention contains some other clauses which should be briefly mentioned:

(1) Differing from the drafts prepared by the Rome Institute and the Secretary-General, the Committee's draft convention defines specifically the categories of persons to which it is applicable. These are ascendants, descendants and spouses [Article 1(a)]. Illegitimate and adopted children were included among the ascendants and descendants. ${ }^{58}$

(2) Claims reduced to judgment (Article 6) and applications for variation of maintenance orders (Article 9) may be transmitted under the terms of the draft convention.

(3) The competent tribunal may, on the basis of the papers submitted to it, make an interim order for the payment of maintenance while the proceedings are pending [Article 7(3)].

(4) Article 8 provides a special procedure enabling the tribunal to obtain further evidence in another country by letters of request (or letters rogatory).

(5) Articles 10 and 11 set forth the exemptions and facilities granted to claimants with respect to costs, security, fees and transfer of funds.

(6) In order to facilitate the participation of federal states, the Committee included a clause whereby no provision of the convention shall be deemed to affect, or to impose any obligation in respect of, any matter not within the constitutional competence of a federal State (Article 14).

\footnotetext{
57 Under the uniform support laws the functions of dependent's representative, which corresponds to the receiving agency in the Committee's draft convention, were given to different organs by the legislatures of the various states of the United States (e.g., an attorney appointed by a board of coinunon pleas judges in Connecticut, the public welfare commissioner in Utah, the solicitor or another official appointed by the city or town in Rhode Island). See Von Otterstedt, sulpra note 47 . The experience of the uniform support laws should be useful in determining which agencies might be used for the purposes of the convention if the United States becomes a party to it.

Es UN document E/AC.39/1, 10.
} 
Draft of a Model Convention on the Enforcement Abroad of Maintenance Orders. - This model followed rather closely the Secretary-General's first working draft. We will therefore examine only the main differences between the two projects.

With respect to the field of application, the Secretary-General's working draft was limited to maintenance orders made by judicial authorities, whereas the Committee's model extended also to other enforceable instruments, such as orders of administrative authorities and arbitral awards (Article 14).

An important difference is to be found in the rules establishing the competence of courts to pronounce maintenance orders. While both the Secretary-General's and the Rome Institute's drafts included among the competent courts those of the country in which the dependent was resident when the proceedings were instituted, the Committee omitted this category (Article 3). Although the Committee was aware that such exclusion would bar many persons from availing themselves of the benefits of the Convention it considered that the model should follow the principle that a court cannot acquire jurisdiction over a defendant who is in another country and has not submitted to the jurisdiction of that court.

The working draft's provision that an application for enforcement may be made through the diplomatic channel was modified to the effect that an application may be made through the authorities designated by the country of the enforcing court.

Articles 5 and 6 , concerning the granting and effect of exequatur or registration, are identical to the corresponding articles of the working draft. The model, however, offered also an alternative method of enforcement for countries not familiar with the exequatur or registration procedure. If an application for enforcement is made to a court of one of those countries, the court would pronounce a new order based upon the recogmition of the original maintenance order.

An innovation of the model consisted in a clause whereby orders subject to variation would be enforceable, and orders for periodic payments would be enforceable with respect to accrued and future instalments, as if the order had been originally pronounced by the enforcing court (Article 7). The exemptions and facilities granted in the model were the same as those established in the Committee's draft multilateral convention.

\section{CONCLUSTON}

Humanitarian reasons call for a simplification of the legal labyrinth in which dependents find themselves when they attempt to obtain support from defaulters abroad. The efforts made over a period of many years by jurists of different lands have culminated in the two drafts submitted by the Committee of Experts to the Economic and Social Council. At the end of its meeting in Geneva, the Committee came to the conclusion that despite the differences which exist among legal systems, it is possible to find a solution compatible with the basic primciples of law governing the various coun- 
tries. While presenting the second draft as a model for consideration by Governments, the Committee hoped that the first draft, if approved by the Council, could be adopfed as a multilateral convention.

Since the participation of the United States in the proposed convention would be a very important element in making it practically effective, the Committee took special care to devise a formula which could be generally acceptable to the American legal system. Being basically inspired by the two-state procedure adopted in the uniform support laws, the draft convention should commend itself to the sympathetic consideration of the legal profession, especially in the State of California where legislators and courts have been most forward-looking on the subject of maintenance obligations and foreign judgments. ${ }^{59}$

The Committee's drafts should also be examined from the viewpoint of legal technique. Regardless of their immediate outcome, these projects might indicate a possible method for a solution of other problems of private international law which are an inevitable companion of the growing interdependence of the modern world.

69 Supra note 28. 